\title{
Battelle Energy Alliance, LLC, Continuity Readiness Assurance Report - Fiscal Year 2015
}

Daniel R. Anderson

September 2015

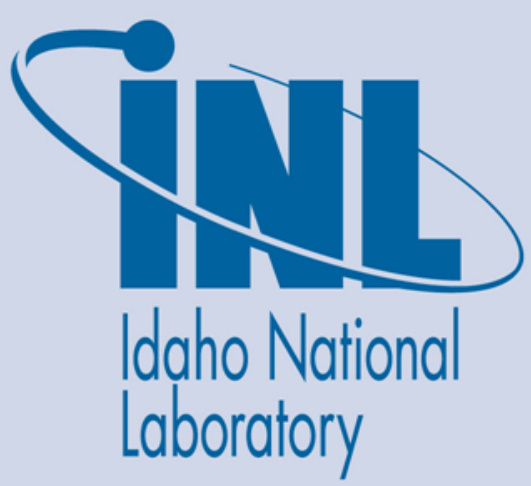

The INL is a U.S. Department of Energy National Laboratory operated by Battelle Energy Alliance 


\section{DISCLAIMER}

This information was prepared as an account of work sponsored by an agency of the U.S. Government. Neither the U.S. Government nor any agency thereof, nor any of their employees, makes any warranty, expressed or implied, or assumes any legal liability or responsibility for the accuracy, completeness, or usefulness, of any information, apparatus, product, or process disclosed, or represents that its use would not infringe privately owned rights. References herein to any specific commercial product, process, or service by trade name, trade mark, manufacturer, or otherwise, does not necessarily constitute or imply its endorsement, recommendation, or favoring by the U.S. Government or any agency thereof. The views and opinions of authors expressed herein do not necessarily state or reflect those of the U.S. Government or any agency thereof. 
INL/EXT-15-35781

Revision 0

\title{
Battelle Energy Alliance, LLC, Continuity Readiness Assurance Report - Fiscal Year 2015
}

\author{
Daniel R. Anderson
}

September 2015

Idaho National Laboratory Emergency Management

Idaho Falls, Idaho 83415

http://www.inl.gov

Prepared for the

U.S. Department of Energy

Under DOE Idaho Operations Office

Contract DE-AC07-05ID14517 



\title{
Emergency Management
}

\section{Battelle Energy Alliance, LLC, Continuity Readiness Assurance Report - Fiscal Year 2015}

\author{
INL/EXT-15-35781 \\ Revision 0 \\ September 2015
}

Approved by:

Carl J. Farmer

INL Emergency Management Department, Manager 



\begin{abstract}
Battelle Energy Alliance, LLC, the prime contractor for Idaho National Laboratory (INL), provides this Continuity Readiness Assurance Report (CRAR) in accordance with DOE O 150.1, "Continuity Programs." This CRAR documents the readiness of the INL Continuity of Operations Program using emergency response planning, recovery actions, and preparedness activities, and where applicable, summarizes and/or provides supporting information for Fiscal Year 2015. This CRAR also provides goals and achievements for Fiscal Year 2016.

Specifically, this CRAR assures the Department of Energy Idaho Operations Office that the emergency capabilities at INL are sufficient to implement the INL Continuity of Operations Plan.
\end{abstract}




\section{CONTENTS}

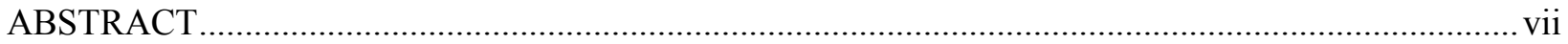

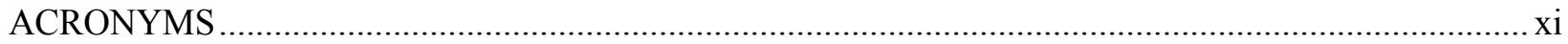

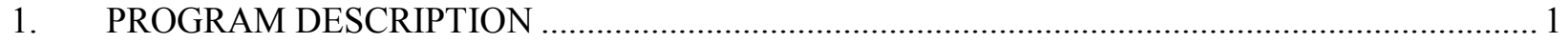

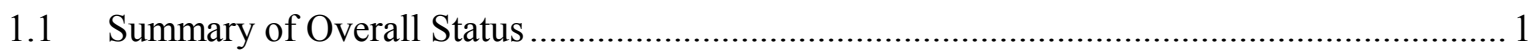

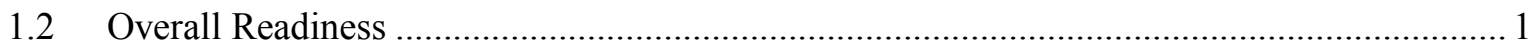

1.3 Limiting Factors Preventing Accomplishment of Essential Functions .................................. 2

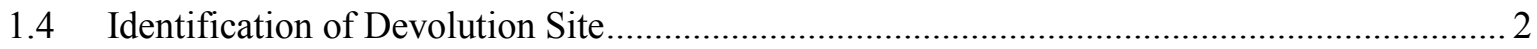

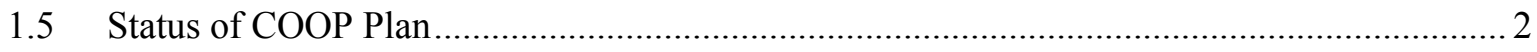

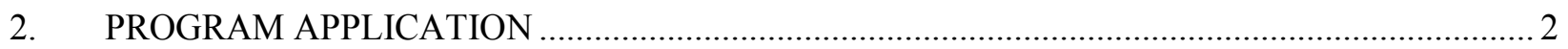

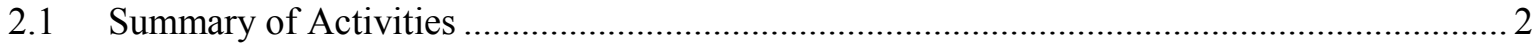

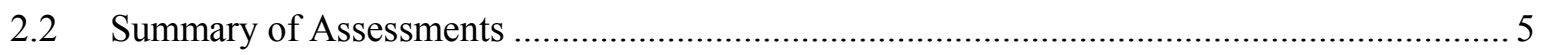

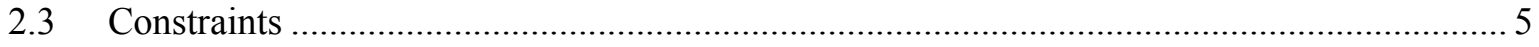

2.4 Program Improvements/Issues/Needs …................................................................... 5

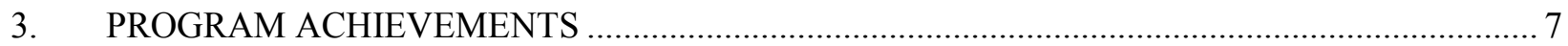

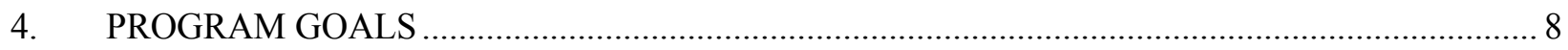

TABLES

Table 1. Equipment checks, testing, training, tabletop drills, and exercises............................................ 3

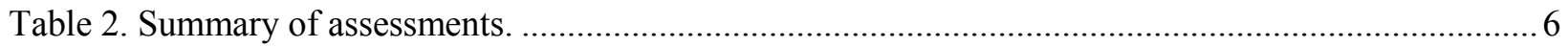




\section{ACRONYMS}

AOF alternate operating facility

BEA Battelle Energy Alliance, LLC

CERG continuity emergency response group

COOP continuity of operations

CRAR Continuity Readiness Assurance Report

DOE Department of Energy

DOE-ID Department of Energy Idaho Operations Office

ESA essential supporting activity

FY Fiscal Year

INL Idaho National Laboratory

LSPT limited scope performance test

PMEF primary mission essential function

WCC Warning Communications Center 


\section{Battelle Energy Alliance, LLC, Continuity Readiness Assurance Report - Fiscal Year 2015 1. PROGRAM DESCRIPTION}

Battelle Energy Alliance, LLC (BEA), is the Department of Energy (DOE) managing and operating contractor for Idaho National Laboratory (INL) at the INL Site near Idaho Falls, Idaho, and Research and Education Campus in Idaho Falls. The INL Continuity of Operations (COOP) Program is an integrated function of the INL Emergency Management Department. PLN-4267, "Idaho National Laboratory Continuity of Operations Plan," was developed in accordance with the applicable requirements in DOE O 150.1, "Continuity Programs," and National Security Presidential Directive-51/Homeland Security Presidential Directive-20. The INL COOP establishes procedures used by BEA during a continuity event. The primary mission essential function (PMEF) is to maintain the safety and security of special nuclear material at INL. The PLN-4267 is an integrated function of the DOE Idaho Operations Office (DOE-ID) and BEA and managed by BEA. It is intended that INL will implement PLN-4267 in conjunction with the DOE-ID COOP Plan (11.OD.02).

PLN-4267 and PLN-2420, "BEA Epidemic/Pandemic Influenza Plan," define the elements of the INL COOP Program.

PLN-4267 applies to all INL personnel and INL programs and essential supporting activities (ESAs) related to the performance of the INL primary mission essential function (PMEF). The objectives of PLN-4267 are to:

- Maintain a high level of readiness

- Protect personnel and visitors from dangerous conditions

- Ensure INL can fulfill its responsibilities for protecting the federal government's legal, financial, and security interests, including critical operational oversight, even when conditions cause INL to operate without its usual support systems and facilities

- Provide at least a minimum level of service required to meet DOE-ID's needs, especially those required at times of local or regional emergencies

- Provide the initial framework for response to any incapacitating event by mission essential personnel to ensure the INL PMEF and ESAs can be performed.

\subsection{Summary of Overall Status}

PLN-4267 establishes the COOP procedures used by BEA and was initially approved by DOE-ID in September 2012. PLN-4267 has been in its third year of implementation for Fiscal Year (FY) 2015. FY-2015 provided the opportunity for the development and maturity of the INL COOP Program. With the successful completion of several assessments, tabletop drills, and the annual exercise during FY-2015, BEA is progressively enhancing the capabilities in establishing a robust and sustainable COOP program.

\subsection{Overall Readiness}

PLN-4267 supports a high level of confidence in continuing the INL PMEF despite circumstances that may limit access to resources, including personnel, facilities, information systems, and communications. The INL PMEF has line-of-sight to, or supports the performance of, the DOE-ID PMEF and ultimately the DOE mission essential functions/PMEFs and national essential functions, as required by DOE O 150.1 and National Security Presidential Directive-51/Homeland Security Presidential Directive-20. 
To ensure the overall readiness of the INL COOP Program, the program has established the framework and associated mechanisms for assuring that PLN-4267, implementing procedures, and resources are adequate by ensuring that they are sufficiently maintained, exercised, and evaluated (including assessments and corrective actions) and that appropriate and timely improvements are made in response to needs identified through coordinated and comprehensive COOP planning, resource allocation, training and drills, exercises, and evaluations. Continuous improvement for ensuring overall readiness comes from implementing corrective actions for findings (such as deficiencies, weaknesses, lessons learned, and opportunities for improvement) in all types of evaluations, including both internal and external evaluations.

\subsection{Limiting Factors Preventing Accomplishment of Essential Functions}

Currently, there are no factors that limit BEA's ability to accomplish designated essential functions.

\subsection{Identification of Devolution Site}

Devolution of command and control refers to the situation in which the INL Site is affected to such a degree that it is unable to function. Authority and responsibility must then be transferred. Should this occur, authority and responsibilities are transferred to the agency not affected. In this case, leadership is assured via the orders of succession, under direction of the senior successor, who reconstitutes a continuity emergency response group (CERG). The CERG assumes responsibility for performing the INL PMEF and as many of the ESAs as possible, or notifies DOE of the inability to perform the functions.

\subsection{Status of COOP Plan}

PLN-4267 was approved in September 2012. PLN-4267 must be reviewed annually, at a minimum, to ensure it is accurate and current. The INL COOP coordinator ensures PLN-4267 is reviewed annually and updated, as necessary. As part of the annual review, the INL COOP coordinator determines whether INL capabilities are sufficient and whether PLN-4267 meets all essential requirements identified in DOE O 150.1. Other aspects of PLN-4267 review include the following:

- Maintaining overall PLN-4267 currency and readiness, to include procedures, equipment, systems, personnel, and rosters

- Addressing and resolving PLN-4267 policy issues

- Advising the INL COOP manager on COOP-related matters

- Coordinating among related plans

- Conducting tests, training, and exercises

- Updating PLN-4267 to incorporate lessons learned from tests, drills, exercises, and any actual events that occurred during the year

\section{PROGRAM APPLICATION}

\subsection{Summary of Activities}

Table 1 identifies the equipment checks, testing, training, tabletop drills, and exercises performed during FY-2015 for BEA. Some of the tasks and criteria identified in Table 1 were generated from INL COOP Program goals for FY-2014 (CCN 233934, September 25, 2014). 
Table 1. Equipment checks, testing, training, tabletop drills, and exercises.

\begin{tabular}{|c|c|c|c|c|c|}
\hline \\
\hline Type & Subtype & Who & Capability & Task & Criteria \\
\hline $\begin{array}{l}\text { General } \\
\text { employee } \\
\text { training }\end{array}$ & $\begin{array}{l}\text { Web-based } \\
\text { training }\end{array}$ & $\begin{array}{l}\text { All BEA employees at INL, } \\
\text { including new hires as part } \\
\text { of initial requirements }\end{array}$ & COOP awareness & $\begin{array}{l}\text { Familiarize BEA employees } \\
\text { at INL with COOP alerts, } \\
\text { notifications, and } \\
\text { deployment procedures } \\
\end{array}$ & $\begin{array}{l}\text { COOP concepts, philosophy, } \\
\text { and expectations understood }\end{array}$ \\
\hline CERG training & $\begin{array}{l}\text { Classroom } \\
\text { training }\end{array}$ & INL CERG & $\begin{array}{l}\text { Qualification and } \\
\text { annual refresher } \\
\text { training }\end{array}$ & $\begin{array}{l}\text { Familiarize CERG members } \\
\text { with communications, } \\
\text { available } \mathrm{AOF}^{1} \text { resources, } \\
\text { COOP concepts, and CERG } \\
\text { responsibilities and } \\
\text { expectations }\end{array}$ & $\begin{array}{l}\text { COOP requirements and } \\
\text { expectations understood }\end{array}$ \\
\hline $\begin{array}{l}\text { LSPT, }{ }^{1} \\
\text { equipment }\end{array}$ & $\begin{array}{l}\text { Test } \\
\text { (maintenance) }\end{array}$ & $\begin{array}{l}\text { INL COOP coordinator, } \\
\text { INL CERG, and INL } \\
\text { mission critical personnel }\end{array}$ & $\begin{array}{l}\text { Communications and } \\
\text { CERG functions }\end{array}$ & $\begin{array}{l}\text { Check equipment and } \\
\text { documentation for primary } \\
\text { and backup AOFs }\end{array}$ & $\begin{array}{l}\text { All systems are functional, } \\
\text { including primary and } \\
\text { alternate communication } \\
\text { pathways and equipment }\end{array}$ \\
\hline $\begin{array}{l}\text { LSPT, } \\
\text { notification }\end{array}$ & Test & $\begin{array}{l}\text { INL COOP coordinator, } \\
\text { WCC, }{ }^{1} \text { and INL CERG }\end{array}$ & $\begin{array}{l}\text { Communications } \\
\text { (Everbridge System) }\end{array}$ & $\begin{array}{l}\text { Test ability to notify CERG } \\
\text { members }\end{array}$ & $\begin{array}{l}\text { Notification is received } \\
\text { (quarterly test) }\end{array}$ \\
\hline LSPT, operations & $\begin{array}{l}\text { Test } \\
\text { (maintenance) }\end{array}$ & $\begin{array}{l}\text { INL COOP coordinator and } \\
\text { INL CERG }\end{array}$ & Vital records & $\begin{array}{l}\text { Access redundant source of } \\
\text { vital records at AOFs }\end{array}$ & $\begin{array}{l}\text { Vital records are accessible } \\
\text { (quarterly update) }\end{array}$ \\
\hline $\begin{array}{l}\text { LSPT, alternate } \\
\text { power }\end{array}$ & \begin{tabular}{|l|} 
Test \\
(maintenance)
\end{tabular} & $\begin{array}{l}\text { INL COOP coordinator and } \\
\text { INL Protective Force }\end{array}$ & Portable generators & \begin{tabular}{|l|} 
Check operability of \\
portable generators and \\
ensure INL Protective Force \\
is maintaining equipment \\
\end{tabular} & $\begin{array}{l}\text { Maintenance schedule is } \\
\text { maintained }\end{array}$ \\
\hline $\begin{array}{l}\text { LSPT, } \\
\text { communications }\end{array}$ & $\begin{array}{l}\text { Test } \\
\text { (maintenance/ } \\
\text { training) }\end{array}$ & $\begin{array}{l}\text { INL COOP coordinator and } \\
\text { INL Protective Force }\end{array}$ & Satellite phones & $\begin{array}{l}\text { Provide training, followed } \\
\text { by simple test, to familiarize } \\
\text { INL Protective Force with } \\
\text { satellite phone capabilities }\end{array}$ & $\begin{array}{l}\text { Equipment operation is } \\
\text { adequate }\end{array}$ \\
\hline $\begin{array}{l}\text { LSPT, } \\
\text { emergency } \\
\text { power }\end{array}$ & $\left|\begin{array}{l}\text { Test, } \\
\text { (maintenance) }\end{array}\right|$ & INL COOP coordinator & $\begin{array}{l}\text { Emergency power at } \\
\text { AOF }\end{array}$ & $\begin{array}{l}\text { Check operability of AOF } \\
\text { equipment when supplied } \\
\text { with power by emergency } \\
\text { power facilities }\end{array}$ & $\begin{array}{l}\text { AOF equipment is operable } \\
\text { with emergency power } \\
\text { supply }\end{array}$ \\
\hline
\end{tabular}


Table 1. (continued).

\begin{tabular}{|c|c|c|c|c|c|}
\hline Type & Subtype & Who & Capability & Task & Criteria \\
\hline Tabletop drill & $\begin{array}{l}\text { Training } \\
\text { development }\end{array}$ & $\begin{array}{l}\text { INL COOP coordinator, } \\
\text { INL CERG; }\end{array}$ & $\begin{array}{l}\text { DOE Recommended } \\
\text { Action Matrix (RAM) } \\
\text { and INL Medical } \\
\text { Condition (MEDCON) } \\
\text { Levels as used during } \\
\text { pandemic event }\end{array}$ & $\begin{array}{l}\text { Develop familiarity with } \\
\text { RAM and MEDCON Levels }\end{array}$ & $\begin{array}{l}\text { Demonstrate understanding } \\
\text { of application of actions as } \\
\text { set forth in RAM and } \\
\text { MEDCON Levels during an } \\
\text { pandemic event }\end{array}$ \\
\hline $\begin{array}{l}\text { LSPT, COOP } \\
\text { Helpline, } \\
\text { communications }\end{array}$ & $\begin{array}{l}\text { Test, } \\
\text { (training) }\end{array}$ & $\begin{array}{l}\text { INL COOP coordinator and } \\
\text { INL CERG }\end{array}$ & COOP Helpline & $\begin{array}{l}\text { Demonstrate ability to } \\
\text { access COOP Helpline to } \\
\text { report personnel } \\
\text { accountability Helpline }\end{array}$ & $\begin{array}{l}\text { CERG demonstrates } \\
\text { increased ability to access } \\
\text { COOP Helpline }\end{array}$ \\
\hline Tabletop Drill & $\begin{array}{l}\text { Training } \\
\text { Development }\end{array}$ & $\begin{array}{l}\text { INL COOP coordinator and } \\
\text { selected Laboratory } \\
\text { Protection managers, } \\
\text { personnel, and cyber } \\
\text { security subject matter } \\
\text { experts }\end{array}$ & Respond to cyber-event & $\begin{array}{l}\text { Identify issues and } \\
\text { challenges posed during a } \\
\text { serious cyber event }\end{array}$ & $\begin{array}{l}\text { Begin process of developing } \\
\text { a robust capability to } \\
\text { continue INL operations } \\
\text { during an ongoing cyber } \\
\text { event }\end{array}$ \\
\hline Discussion & $\begin{array}{l}\text { Supply } \\
\text { upgrade }\end{array}$ & $\begin{array}{l}\text { INL COOP coordinator and } \\
\text { selected INL CERG } \\
\text { personnel }\end{array}$ & $\begin{array}{l}\text { Emergency Food } \\
\text { Supply }\end{array}$ & $\begin{array}{l}\text { Identify options for } \\
\text { replacing existing } \\
\text { emergency food supply }\end{array}$ & $\begin{array}{l}\text { Select cost-effective option } \\
\text { for replacing existing } \\
\text { emergency food supply as } \\
\text { that supply reaches shelf-life } \\
\text { expiration }\end{array}$ \\
\hline Exercise & $\begin{array}{l}\text { Annual } \\
\text { exercise/ } \\
\text { pandemic }\end{array}$ & INL CERG & $\begin{array}{l}\text { Ability to implement } \\
\text { INL MEDCON Levels } \\
\text { in conjunction with } \\
\text { implementation of } \\
\text { DOE RAM }\end{array}$ & $\begin{array}{l}\text { Conduct exercise to provide } \\
\text { selected INL CERG } \\
\text { members and supporting } \\
\text { personnel opportunity to } \\
\text { respond to and mitigate } \\
\text { COOP event }\end{array}$ & $\begin{array}{l}\text { Initiate appropriate INL } \\
\text { MEDCON Level as } \\
\text { warranted by situation as it } \\
\text { develops during an } \\
\text { pandemic; initiate } \\
\text { appropriate RAM in } \\
\text { conjunction with INL } \\
\text { MEDCON Level } \\
\end{array}$ \\
\hline \multicolumn{6}{|c|}{$\begin{array}{l}\text { AOF }=\text { alternate operating facility } \\
\text { LSPT }=\text { limited scope performance test } \\
\text { WCC }=\text { Warning Communications Center }\end{array}$} \\
\hline
\end{tabular}




\subsection{Summary of Assessments}

The INL Issues Management Program ensures issues that have a reasonable potential to cause adverse operational, environmental, safety and health, or quality assurance consequences are documented and resolved in an effective and timely manner. The program is designed to be an integrated BEA process that enables management to understand and prioritize, based on risk and significance, the correction of issues. The program also provides for ensuring that adequate corrective actions are implemented to prevent recurrence of undesirable events or conditions through appropriate causal analysis, corrective action, verification, and follow-up actions.

Issues identified in the INL COOP Program during exercises and actual emergencies are noted and discussed during event critiques. Methods are determined to resolve the concerns and a schedule is prepared to implement the resolution. Once identified, issues are screened and, if appropriate, entered into the Laboratory Protection LabWay for electronic tracking. Corrective action plans are prepared and the issues tracked until resolved.

Table 2 identifies the issues that the INL COOP Program had identified and entered into the Laboratory Protection LabWay during FY-2015.

\subsection{Constraints}

There are no constraints at this time.

\subsection{Program Improvements/lssues/Needs}

Table 2 lists the seven issues that were entered into the Laboratory Protection LabWay during FY2015. Of those seven issues, three were closed with four remaining issues carrying into FY-2016. 
Table 2. Summary of assessments.

\begin{tabular}{|c|c|c|}
\hline Issue & Action & Status \\
\hline Emergency Food Supply nearing expiration date & $\begin{array}{l}\text { Provide for yearly rotation of } 1 / 3 \text { of the current supply; consider } \\
\text { replacing MREs with freeze-dried meals with a longer shelf life } \\
\text { if testing shows that palatability is comparable. }\end{array}$ & Open \\
\hline $\begin{array}{l}\text { DOE implementation of Recommended Action Matrix (RAM) in } \\
\text { place of MEDCON levels for dealing with pandemic influenza }\end{array}$ & $\begin{array}{l}\text { Use Annual Exercise to test feasibility of integrating RAM while } \\
\text { retaining MEDCON levels with Key Actions as site-specific } \\
\text { approach. }\end{array}$ & Closed \\
\hline $\begin{array}{l}\text { Effects of cyber-attack on confidentiality and integrity of } \\
\text { information directly related to safety and security of special } \\
\text { nuclear material }\end{array}$ & $\begin{array}{l}\text { Evaluate the effects of cyber-attack on confidentiality and } \\
\text { integrity of information directly related to safety and security of } \\
\text { special nuclear material. }\end{array}$ & Open \\
\hline $\begin{array}{l}\text { Emergency power generators accountability list does not match } \\
\text { serial numbers of generators deployed and in storage. }\end{array}$ & $\begin{array}{l}\text { Compile a corrected list of serial numbers for transmission to } \\
\text { Protective Force Logistics. }\end{array}$ & Closed \\
\hline $\begin{array}{l}\text { COOP Integrated Assessment System information sometimes } \\
\text { does not reflect correct contact information or categorization of } \\
\text { activities. }\end{array}$ & Reconcile actual COOP information with IAS information. & Open \\
\hline $\begin{array}{l}\text { Proposed DOE Order 151.1A could expand the scope of BEA's } \\
\text { COOP responsibilities beyond the "safety and security of SNM" } \\
\text { as defined under correspondence CCN } 217606 \text {, June 4, } 2009 .\end{array}$ & $\begin{array}{l}\text { Provide input to management regarding the possibility of } \\
\text { expansion of COOP responsibilities under proposed DOE Order } \\
151.1 \mathrm{~A} \text { and suggest that an updated letter from DOE contracting } \\
\text { officer might be necessary to limit scope of COOP } \\
\text { responsibilities to safety and security of SNM if no additional } \\
\text { funding is available. }\end{array}$ & Closed \\
\hline $\begin{array}{l}\text { COOP Vital Records electronic back-up lacks ability to include a } \\
\text { Table of Contents. }\end{array}$ & $\begin{array}{l}\text { While assisting in efforts to create electronic copies of ATR-C } \\
\text { documents, determine whether better technology makes possible } \\
\text { the creating of electronic Table of Contents for COOP Vital } \\
\text { Records. }\end{array}$ & Open \\
\hline
\end{tabular}




\section{PROGRAM ACHIEVEMENTS}

FY-2015 has provided several opportunities for the growth and further development of the INL COOP Program. Several goals set during FY-2014 were successfully completed during the FY-2015 assessment, drills/exercise, and training opportunities.

The ability to continue INL operations during a cyber-event received additional focus during FY2015. The COOP 2014 annual exercise provided a foundation upon which the INL COOP Program was able to build during FY-2015. During the FY-2014 annual exercise, the INL COOP Program demonstrated the ability to provide uninterrupted safety and security of special nuclear material during a cyber-event that severely impacted computer and cyber service. From this foundation, the INL COOP Program coordinated and facilitated a tabletop drill for selected Laboratory Protection managers and personnel, in cooperation with cyber-security subject matter experts, which moved the organization forward in developing a robust ability to continue operations during a serious cyber-event. As a result, Laboratory Protection will serve as a model for other INL organizations in developing the ability to continue INL missions during a cyber-event.

Following the Laboratory Protection cyber tabletop, the INL COOP program continued to support cyber security subject matter experts in their efforts to increase INL-wide preparedness. The INL COOP program participated in meetings with leadership management teams (LMTs) from INL organizations in preparation for a tabletop discussion with the LMTs. The tabletop raised awareness and began the process of assessing the impacts on INL organizations of a severe cyber-attack.

Simultaneously with preparation for the cyber-event Tabletop, the INL COOP Program maintained focus on implementing training for continuing operations during an influenza pandemic. The COOP Program provided training in the newly introduced DOE Recommended Action Matrix (RAM), with which DOE intended to replace the DOE MEDCON levels. The COOP Program determined to maintain use of the MEDCON levels as a site-specific measure and to implement the DOE RAM in conjunction and coordination with the existing MEDCON levels. As a result, the COOP pandemic response will maintain the ability to take appropriate preparatory actions as an influenza pandemic poses an increasing threat to INL operations, while managing communications with INL personnel to minimize unnecessary alarm and maximizing transmission of useful information to affected organizations and personnel.

The INL COOP Program provided training to the INL CERG members in the access and use of the COOP automated Helpline. This resource will enable the CERG to provide for accountability remotely during a COOP event. Participation in the training nearly doubled as compared to FY-2014.

The INL COOP Program was asked to evaluate the impact, and to submit input, regarding the implementation of DOE Order 150.1A. The COOP Program suggested that a re-issuance of a letter, which substantially incorporates the content of EM preauthorization (CCN 217606, June 4, 2009), would be useful. This suggestion was adopted.

The INL COOP Program called attention to the fact that our emergency food supply, which currently consists of Meals Ready to Eat (MREs) is nearing its expirations date. The COOP Program observed that MREs have a shelf life of 3-5 years, and that continued need to rotate this supply will create a significant ongoing expense. The COOP Program conducted research into other possible options and presented those options to the selected CERG members for consideration and discussion. As a result, the CERG identified freeze-dried meals as an option for an emergency food supply that has a demonstrated shelf life of at least 30 years under proper conditions. This option will drastically reduce the costs associated with maintaining the emergency food supply. 


\section{PROGRAM GOALS}

For FY-2016, the INL COOP Program is looking forward to another successful year of implementing PLN-4267. Realizing there is always room for improvement for the growth of the program, BEA has identified areas to improve proficiency in the way INL manages the INL COOP Program. Along with evaluating new ideas, the program will continue to provide training opportunities and provide assessments of the program to further enhance its capabilities.

INL COOP Program goals for FY-2016, many of which are driven by DOE O 150.1, are as follows:

- Conduct a COOP exercise to test INL COOP response.

- Continue to assist and support implementation of measures to develop an effective response to a cyber-event.

- Provide CERG orientation on responsibilities and equipment.

- Provide all BEA employees at INL awareness training on COOP alerts, notifications, and accountability.

- Review PLN-4267 and update, as necessary, to include incorporating changes in policy (specifically DOE Order 150.1A) and philosophy and managing distribution of plan revisions.

- Maintain and update, as needed, orders of succession of current incumbents and designated successors.

- Update vital records to ensure they are current.

- Update CERG rosters of positions and information, if needed.

- Develop tabletop drill subtypes that consider training development opportunities and/or vulnerability assessments.

- Conduct LSPTs on equipment, the notification process, vital records, emergency power, and the accountability process.

- Evaluate and look for ways to improve interaction with the Emergency Operations Center Emergency Response Organization to ensure a strong cohesiveness in preparing for what emergencies might occur in the future.

- Track and evaluate the participation of CERG members in training activities. In doing so, ensure the INL COOP Program has meaningful training activities that encourage participation.

- Follow the development and implementation of DOE O 150.1A, "Continuity Programs," and update PLN-4267, as necessary.

- Monitor and provide necessary support in implementing replacement of the emergency food supply.

- Evaluate and look for ways to improve interfaces and integration opportunities to work with

COOP-related organizations. 